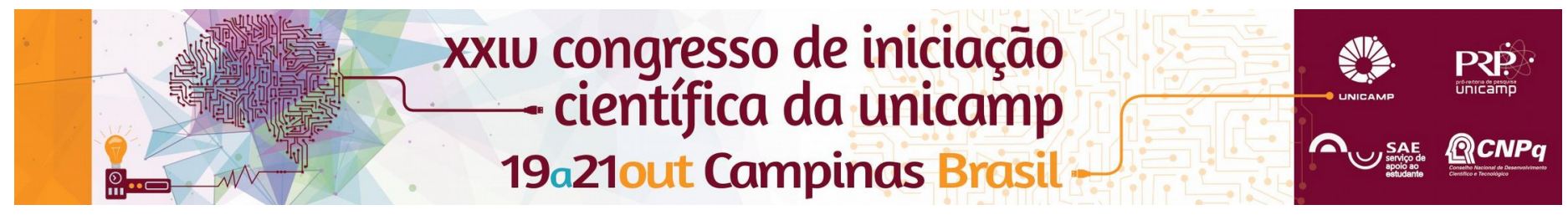

\title{
Paisagens do café na região de Limeira-SP: memórias de sabor e de lugar
}

\section{Eduardo José Marandola Jr, Raissa Salgado Rodrigues}

\begin{abstract}
Resumo
O projeto se propõe a investigar a paisagem do café da região de Limeira-SP, compreendendo seus sentidos revelados através das memórias gustativas. Estudar a paisagem de modo fenomenológico possibilita entender a constituição da região em questão e de seus respectivos lugares. Além disso, caminharemos para um avanço no que se refere à formulação das políticas de salvaguarda de patrimônios naturais e/ou culturais e imateriais, como no caso da paisagem cafeeira.
\end{abstract}

Palavras-chave:

Políticas de salvaguarda, Patrimônio, Paisagem.

\section{Introdução}

O turismo, como atividade estritamente econômica, fundamentou justificativas para preservar e conservar aspectos culturais, materiais e imateriais dos lugares. No entanto, algumas questões precisando ser problematizadas no que se refere ao processo de salvaguarda: o que e porque preservar um patrimônio histórico? Que influência sofre uma paisagem, um lugar, uma cultura que é salvaguardada?

A paisagem é um elemento fundamental para a salvaguarda, pois é um eixo estruturador, seja para preservação de elementos naturais ou culturais (DETONI, 2012). Deste modo, é partindo de um estudo fenomenológico da paisagem do café na região de Limeira-SP que aspectos acerca de sua formação podem ser revelados e explorados, não sendo relevante o fato da cultura do café em larga escala estar extinta na cidade.

Neste sentido, a memória gustativa tem um importante papel nesta investigação. Elas podem ser obtidas por meio de relatos de moradores de Limeira-SP e uma vez que a memória compõe os lugares não uma genealogia deslocada no tempo, mas presentificando os elementos do mesmo, conforme Lowenthal (1999). A memória é vivida, não significando uma representação, mas se presentificando a cada lembrança (RICOUER, 2001).

\section{Resultados e Discussão}

As memórias de uma paisagem ou de lugar são expressas através de sua morfologia, arquitetura e também pelos relatos das pessoas que nele vivem ou viveram. Escavar essas memórias é movimentar a paisagem, alimentando seu processo vivo, dinâmico e atemporal.
As memórias são aspectos de uma paisagem que visualmente pode estar acabada, como a paisagem do café na região de Limeira-SP, no entanto, se existem fazendas históricas, avenidas que levam nomes dos Barões do café, e pessoas que em algum momento de suas vidas lidaram com a cultura do respectivo grão ou que viram familiares e conhecidos, é um sinal claro de que a paisagem do café está viva e relembrar esta época é tornar a paisagem ainda mais evidente.

\section{Conclusão}

O projeto caminha para a finalização, mas já é possível destacar que a paisagem do café na região de LimeiraSP tem duas principais vertentes. Há uma paisagem decantada na histórica, pois suas memórias foram esquecidas após a morte de quem as carregava. Há também a paisagem viva do café, anunciada por pessoas que muito tem a dizer e experienciar das mesmas, ainda que com saudade e desejo de regresso a um tempo longínquo, porém muito marcante.

\section{Agradecimentos}

Ao PIBIC/Unicamp e ao orientador Eduardo Marandola Jr.

RICOEUR, Paul. A história, a memória, o esquecimento. Campinas: Ed. UNICAMP, 2001.

DETONI, S. F. Tombamento De Áreas Naturais: A Paisagem Como Elemento Estruturador. Revista Geonorte, Manaus, 2012. 